\title{
Lactobacillus arizonensis sp. nov., isolated from jojoba meal
}

\author{
J. L. Swezey, L. K. Nakamura, T. P. Abbott and R. E. Peterson
}

Author for correspondence: L. K. Nakamura. Tel: +1 309681 6395. Fax: + 1309681 6672. e-mail: lnakamura@sunca.ncaur.usda.gov

Microbial Properties Research Unit, National Center for Agricultural Utilization Research, 1815 North University Street, Agricultural Research Service, US Department of Agriculture, Peoria, IL 61604 USA

\begin{abstract}
Five strains of simmondsin-degrading, lactic-acid-producing bacteria were isolated from fermented jojoba meal. These isolates were facultatively anaerobic, Gram-positive, non-motile, non-spore-forming, homofermentative, rod-shaped organisms. They grew singly and in short chains, produced lactic acid but no gas from glucose, and did not exhibit catalase activity. Growth occurred at 15 and $45^{\circ} \mathrm{C}$. All strains fermented cellobiose, D-fructose, D-galactose, D-glucose, lactose, maltose, D-mannitol, D-mannose, melibiose, D-ribose, salicin, D-sorbitol, sucrose and trehalose. Some strains fermented L-(-)-arabinose and L-rhamnose. D-Xylose was not fermented and starch was not hydrolysed. The mean G+C content of the DNA was 48 mol\%. Phylogenetic analyses of 165 rDNA established that the isolates were members of the genus Lactobacillus. DNA reassociation of $45 \%$ or less was obtained between the new isolates and the reference strains of species with $\mathrm{G}+\mathrm{C}$ contents of about $48 \mathrm{~mol} \%$. The isolates were differentiated from other homofermentative Lactobacillus spp. on the basis of 165 rDNA sequence divergence, DNA relatedness, stereoisomerism of the lactic acid produced, growth temperature and carbohydrate fermentation. The data support the conclusion that these organisms represent strains of a new species, for which the name Lactobacillus arizonensis is proposed. The type strain of $L$. arizonensis is NRRL B-14768 ${ }^{\top}$ (= DSM 13273').
\end{abstract}

Keywords: new species, taxonomy, simmondsin degrader, jojoba, Lactobacillus arizonensis

\section{INTRODUCTION}

Jojoba (Simmondsia chinensis) is an important commercial seed crop grown in the desert southwestern United States. Up to $60 \%$ of the seed weight consists of a unique oil that is used in the cosmetic and skin care industry. After hexane extraction of the oil, the remaining meal contains $25-30 \%$ crude protein, is high in fibre and could be a valuable cattle feed supplement. However, this meal is not currently fed to animals because it contains 5-demethyl simmondsin, 4,5-didemethylsimmondsin, simmondsin and simmondsin 2'-ferulate (Elliger et al., 1973, 1974a, b; Verbiscar \& Banigan, 1978). These substances are cyanogenic toxins that have been implicated in weight

The GenBank accession number for the $16 \mathrm{~S}$ rDNA sequence of Lactobacillus arizonensis sp. nov. is AF093757. loss of ruminants (Manos et al., 1986) and in the death of mice (Weber et al., 1983).

Studies by Verbiscar et al. (1981) indicated that Lactobacillus spp. attacked simmondsin in autoclaved meal but not when used as a sole carbon source in culture media. As the result of a screening effort, Abbott et al. (1990) obtained isolates of Stenotrophomonas maltophilia, 'Flavobacterium aurantiacum' and Fusarium moniliforme that attacked simmondsin when used as a sole carbon source; however, only $F$. moniliforme degraded simmondsin effectively in the meal. Microbiological evaluation of large batches of meal inoculated with $F$. moniliforme and incubated out of doors revealed the involvement of bacteria as well as fungi in the simmondsin-degrading process.

The purpose of this study was to identify the simmondsin-degrading bacteria isolated from fermented jojoba meal. The results indicate that the simmondsin-de- 
grading isolates represent strains of a new Lactobacillus species.

\section{METHODS}

Bacterial strains. The strains were isolated from sterile jojoba meal that had been inoculated with $F$. moniliforme and fermented for $20 \mathrm{~d}$ in the open air of Hyden Valley Desert in Arizona. One gram samples of meal were suspended in $100 \mathrm{ml} 0 \cdot 85 \%(\mathrm{w} / \mathrm{v})$ sterile saline and $0.2 \mathrm{ml}$ serial dilutions were spread on modified Rogosa SL agar in which the dextrose, L- $(+)$-arabinose and sucrose was replaced by $0.5 \%(\mathrm{w} / \mathrm{v})$ simmondsin. Incubation was at $37^{\circ} \mathrm{C}$ in an anaerobic jar having a $\mathrm{H}_{2}+\mathrm{CO}_{2}$ environment generated with a BBL Gas Pak (Becton Dickinson Microbiology Systems). Small, white, opaque, raised colonies appearing after $48 \mathrm{~h}$ were streaked onto MRS agar for purification.

The reference strains used in the DNA reassociation studies were Lactobacillus amylophilus NRRL B- $4437^{\mathrm{T}}$, Lactobacillus coryniformis NRRL B-4391 ${ }^{\mathrm{T}}$, Lactobacillus plantarum NRRL B-4496 ${ }^{\mathrm{T}}$, Lactobacillus paracasei subsp. paracasei NRRL B-4560, Lactobacillus rhamnosus NRRL B$176^{\mathrm{T}}$, Lactobacillus casei subsp. casei NRRL B-1922 ${ }^{\mathrm{T}}$, Lactobacillus delbrueckii subsp. delbrueckii NRRL B-763 ${ }^{\mathrm{T}}$ and Lactobacillus pentosus NRRL B-473 ${ }^{\mathrm{T}}$. These strains are maintained at the Agricultural Research Service Culture Collection at the National Center for Agricultural Utilization Research, Peoria, IL, USA.

Characterization tests. Carbohydrate fermentation tests were conducted in modified MRS medium (Kandler \& Weiss, 1986) with $0.0016 \%$ (w/v) bromocresol purple as an indicator. Inverted Durham tubes were placed in the broth tubes to detect gas production. Starch utilization was determined by growing micro-organisms on MRS agar plates containing $0.5 \%(\mathrm{w} / \mathrm{v})$ soluble starch. The hydrolysis of starch was detected by flooding the plates with $1.0 \mathrm{ml}$ iodine solution $\left(0.2 \mathrm{~g} \mathrm{I}_{2}\right.$ and $2.0 \mathrm{~g} \mathrm{KI}$ in $100 \mathrm{ml}$ distilled water). To determine growth at different temperatures (10, $15,20,25,30,35,40,45$ and $50^{\circ} \mathrm{C}$ ), preincubated sterile medium in $15 \times 150 \mathrm{~mm}$ screw-capped test tubes was inoculated and incubated in a Control Environment Incubator (New Brunswick Scientific).

Inocula for the characterization tests were prepared from cultures grown for $24 \mathrm{~h}$ at $37^{\circ} \mathrm{C}$ in MRS broth. Cells were harvested by centrifugation at $4{ }^{\circ} \mathrm{C}$, washed in sterile $0.85 \%$ saline and resuspended in sterile saline solution. One-tenth millilitre aliquots of inoculum were added to each test tube containing $6 \mathrm{ml}$ medium. All tests were run in duplicate and incubated at $37^{\circ} \mathrm{C}$ in an anaerobic jar with the screw caps loosened; readings were taken at 1,5 and $10 \mathrm{~d}$.

Simmondsin degradation was determined by growing the isolates in deep liver medium (McClung \& McCoy, 1934), which was modified to contain $5 \mathrm{~g}^{-1}$ simmondsin instead of glucose as the carbohydrate source. Samples of the fermented broth were filtered through a $0.45 \mu \mathrm{m}$ pore size Millipore membrane and frozen. Ten microlitre aliquots of the sample were injected into a HPLC system consisting of an SP8800 ternary pump (Spectra-Physics), ISCO V ${ }^{4}$ absorbance detector (Isco), Econosphere C-18 $3 \mu \mathrm{m} 100 \times 4.6 \mathrm{~mm}$ i.d. column (Alltech) and a central ModComp 32/85 computer system (Modular Computer Systems). A linear $5-100 \%$ aqueous methanol gradient over $10 \mathrm{~min}$ at $0.75 \mathrm{ml} \mathrm{min}-1$ was used for all determinations. Column effluents were monitored at $220 \mathrm{~nm}$. Analysis time per sample, including re-equilibration, was typically $20 \mathrm{~min}$. Peak areas in samples of fermentation media with no toxin (i.e. media blanks) were subtracted from sample peak areas. Toxin peak area in fermented samples (after media subtraction) was divided by toxin peak area in unfermented samples to determine the fraction of toxin that was not degraded. The retention time of simmondsin was $8.9 \mathrm{~min}$.

Analyses of metabolic acid products. The concentration of lactic acid and other organic acids was measured by HPLC of cell-free supernatant of cultures incubated for 1 and $6 \mathrm{~d}$ in deep liver medium. The organic acids and other medium components were resolved on a HPX-87H column (BioRad) and monitored with a refractive index detector (Shimizu et al., 1989).

To determine the stereoisomerism of the lactic acid products, cultures were grown for $48 \mathrm{~h}$ at $37^{\circ} \mathrm{C}$ in $11 \mathrm{MRS}$ broth modified to contain $1 \%(\mathrm{w} / \mathrm{v})$ glucose. To prepare samples for assay, $15 \mathrm{ml}$ culture liquor was centrifuged at $10000 \mathrm{~g}$ for $15 \mathrm{~min}$ at $4{ }^{\circ} \mathrm{C}$, and the resulting supernatant was deproteinized by titration with concentrated $\mathrm{NaOH}$ to $\mathrm{pH} 7.6$ in the presence of $2.5 \%(\mathrm{w} / \mathrm{v}) \mathrm{ZnSO}_{4}$. The precipitate was removed by centrifugation at $4{ }^{\circ} \mathrm{C}$ and the supernatant was analysed. Beef heart L- $(+)$-lactate dehydrogenase (EC 1.1.1.27) and Lactobacillus leichmannii $\mathrm{D}-(-)$-lactate dehydrogenase (EC 1.1.1.28) were used for assessing the stereoisomerism of the lactic acid produced by the simmondsin-degrading isolates. Enzymes were purchased from Boehringer Mannheim. The method used was that of Latorre-Guzman et al. (1977). The assay mixture consisted of $0 \cdot 1 \mathrm{ml}(50 \mu \mathrm{g})$ enzyme solution, $2.0 \mathrm{ml}$ glycine/hydrazine sulfate buffer $[7.5 \%(\mathrm{w} / \mathrm{v})$ glycine, $5 \cdot 2 \%(\mathrm{w} / \mathrm{v})$ hydrazine sulfate, $0 \cdot 2 \%(\mathrm{w} / \mathrm{v})$ sodium EDTA and $4.0 \%$ (w/v) $\mathrm{NaOH} ; \mathrm{pH} 9.5], 0.1 \mathrm{ml} 56 \mathrm{mM}$ NAD solution, $0.1 \mathrm{ml}$ of appropriately diluted sample and $0.7 \mathrm{ml}$ distilled water. Uninoculated broths with and without L$(+)$ - and D- $(-)$-lithium lactate were used as controls. The above-mentioned enzymes showed specificity for their respective substrates. Substrate utilization, indicated by NAD reduction, was monitored at $340 \mathrm{~nm}$ in a UV-VIS Thermal Analyzer System (Gilford Systems).

DNA base composition and reassociation. DNA was extracted and purified by a modification of the method of Marmur (1961). The modification involved the use of hydroxyapatite (Bio-Gel HTP; Bio-Rad) chromatography (Markov \& Ivanov, 1974) to produce highly purified DNA preparations. The purity and quality of each DNA preparation were checked by monitoring the absorbance ratio at $260 / 280 \mathrm{~nm}(1 \cdot 8-1 \cdot 9)$ and at 260/230 nm (2.0-2.3) (according to Marmur, 1961) and by the melting curves, which showed hyperchromicity values from 38 to $40 \%$ (Mandel \& Marmur, 1968).

The $\mathrm{G}+\mathrm{C}$ content of the DNA was estimated by the buoyant density method (Schildkraut et al., 1962). Buoyant density of the DNA was measured by $\mathrm{CsCl}_{2}$ density gradient centrifugation in a Beckman Instrument model $\mathrm{E}$ ultracentrifuge. 'Micrococcus lysodeikticus' DNA served as an internal standard.

DNA reassociation values were obtained by a spectrophotometric method described previously (Nakamura \& Swezey, 1983). Percentage relatedness values were calculated by the equation of DeLey et al. (1970). All DNA reassociation determinations were repeated twice.

16S rDNA sequencing. A $16 \mathrm{~S}$ rDNA fragment of strain NRRL B-14768 ${ }^{\mathrm{T}}$ that corresponds to positions 9-1510 of 
Table 1. Characteristics useful for differentiating the simmondsin degraders (SD) from other Lactobacillus species

+ , Positive; -, negative; d, strain variation.

\begin{tabular}{|c|c|c|c|c|c|c|c|c|c|}
\hline \multirow[t]{2}{*}{ Character } & \multicolumn{9}{|c|}{ Organism: } \\
\hline & SD & $\begin{array}{c}\text { L. plant- } \\
\text { arum* }^{*}\end{array}$ & L. pentosus $\dagger$ & $\begin{array}{c}\text { L. para- } \\
\text { casei* }^{*}\end{array}$ & $\begin{array}{l}\text { L. coryni- } \\
\text { formis* }\end{array}$ & $\begin{array}{c}\text { L. amylo- } \\
\text { philus* }\end{array}$ & $\begin{array}{c}\text { L. del- } \\
\text { brueckiï }\end{array}$ & $\begin{array}{c}\text { L. para- } \\
\text { casei }^{*}\end{array}$ & L. casei* \\
\hline $\mathrm{G}+\mathrm{C}(\mathrm{mol} \%)$ & 48 & 45 & 47 & 46 & 45 & 45 & 50 & 46 & 46 \\
\hline $\begin{array}{l}\text { Stereoisomer of } \\
\text { lactic acid }\end{array}$ & DL & DL & DL & DL & $\mathrm{D}-(-)$ & $\mathrm{L}-(+)$ & $\mathrm{D}-(-)$ & $\mathrm{L}-(+)$ & $\mathrm{L}-(+)$ \\
\hline Growth at $15^{\circ} \mathrm{C}$ & + & + & + & + & + & + & - & + & + \\
\hline Growth at $45^{\circ} \mathrm{C}$ & + & - & - & - & - & - & + & + & - \\
\hline $\begin{array}{l}\text { Simmondsin } \\
\text { degradation }(\%)\end{array}$ & 90 & 2 & 20 & 0 & 0 & 0 & 0 & 70 & 0 \\
\hline \multicolumn{10}{|l|}{ Fermentation of: } \\
\hline L-( - )-Arabinose & $\mathrm{d}$ & $\mathrm{d}$ & $\mathrm{d}$ & - & - & - & - & $\mathrm{d}$ & - \\
\hline Mannitol & + & + & + & + & + & - & - & + & + \\
\hline Melibiose & + & + & + & - & $\mathrm{d}$ & - & - & - & - \\
\hline Raffinose & + & + & + & - & $\mathrm{d}$ & - & - & - & - \\
\hline L-Rhamnose & $\mathrm{d}$ & - & $\mathrm{d}$ & - & + & - & - & + & - \\
\hline D-Ribose & + & + & + & + & - & - & - & + & + \\
\hline Sorbitol & + & + & + & + & $\mathrm{d}$ & - & - & + & + \\
\hline Starch & - & - & - & - & - & + & $\mathrm{d}$ & - & - \\
\hline Trehalose & + & + & + & + & - & - & - & + & + \\
\hline D-Xylose & - & $\mathrm{d}$ & + & - & - & - & - & - & - \\
\hline
\end{tabular}

* According to Kandler \& Weiss (1986).

$\dagger$ According to Zanoni et al. (1987).

Escherichia coli 16S rRNA was amplified by PCR, using purified DNA and a primer combination consisting of forward primer $27 \mathrm{f}$ and reverse primer 1492r (Lane, 1991). After purification with the GENE-CLEAN II kit (Bio101), the amplification products were sequenced with a Prism ABI dideoxy terminator cycle sequencing kit manufactured by Applied Biosystems. The manufacturer's recommended protocols were followed. Sequences were determined with the automated Applied Biosystems DNA sequencer. The following primers cited by Lane (1991) were used for sequence analyses: 27f, 530f, 1114f, 1406f, 109r1, 342r, $685 \mathrm{r} 3,907 \mathrm{r}, 1100 \mathrm{r}$ and $1492 \mathrm{r}$. In addition, two other primers, designated 304f (5'-GTAGCCGACCTGAGAGG-3') and 801f (5'-AACAGGATTAGATACCC-3'), were designed to obtain unambiguous results. The CLUSTAL v (Higgins et al., 1992) program was used to align the $16 \mathrm{~S}$ rRNA gene sequence generated with sequences of selected members of the family Lactobacillaceae obtained from GenBank. A similarity matrix was constructed from the aligned sequences. Genetic distances were computed by using the twocorrection model (Kimura, 1980) and used for neighbourjoining analysis.

Confidence limits of the groupings were estimated by bootstrap analysis (500 replications). Phylogenetic trees were constructed using the neighbour-joining and maximumparsimony methods provided by PAUP $4.0 \mathrm{~b} 1$ (Sinauer Associates, Sunderland, MA, USA); both methods produced trees with similar topologies.

The GenBank accession number for the 16S rRNA gene sequence of NRRL B-14768 ${ }^{\mathrm{T}}$ is AF093757.

\section{RESULTS}

\section{Morphology and physiology}

The five simmondsin-degrading isolates (NRRL B$14768^{\mathrm{T}}$, NRRL B-14769, NRRL B-14770, NRRL B14771 and NRRL B-14772) were Gram-positive, nonmotile rods that occurred singly or in short chains. Phase-contrast microscopic examinations of broth or agar cultures grown aerobically or anaerobically revealed no spores after 2 weeks incubation at $37^{\circ} \mathrm{C}$. Granules were noted in some microscopically observed Gram-stained cells. Mean cell measurements were $1 \times 4-5 \mu \mathrm{m}$. Colonies on MRS agar were white, smooth, circular, convex and opaque. The isolates grew at both 15 and $45^{\circ} \mathrm{C}$ but not at 10 or $50^{\circ} \mathrm{C}$, and optimally at $35-40{ }^{\circ} \mathrm{C}$ (based on visual inspection). They were catalase-negative and failed to hydrolyse starch. The isolates grew anaerobically and at initial $\mathrm{pH}$ values that ranged from 4.5 to $8 \cdot 0$; the $\mathrm{pH}$ was adjusted with 1 and $5 \mathrm{M} \mathrm{HCl}$ or $\mathrm{NaOH}$. Growth was not detected in MRS medium that lacked a metabolizable sugar. All isolates degraded approximately $90 \%$ of the simmondsin after $6 \mathrm{~d}$. By comparison, 0-70\% degradation was recorded from the other Lactobacillus reference strains examined (Table 1). The fermentation pattern of the carbohydrates listed in Table 1 was useful for differentiating the isolates from the recognized species. Mannitol, melibiose, raffinose, D-ribose, 


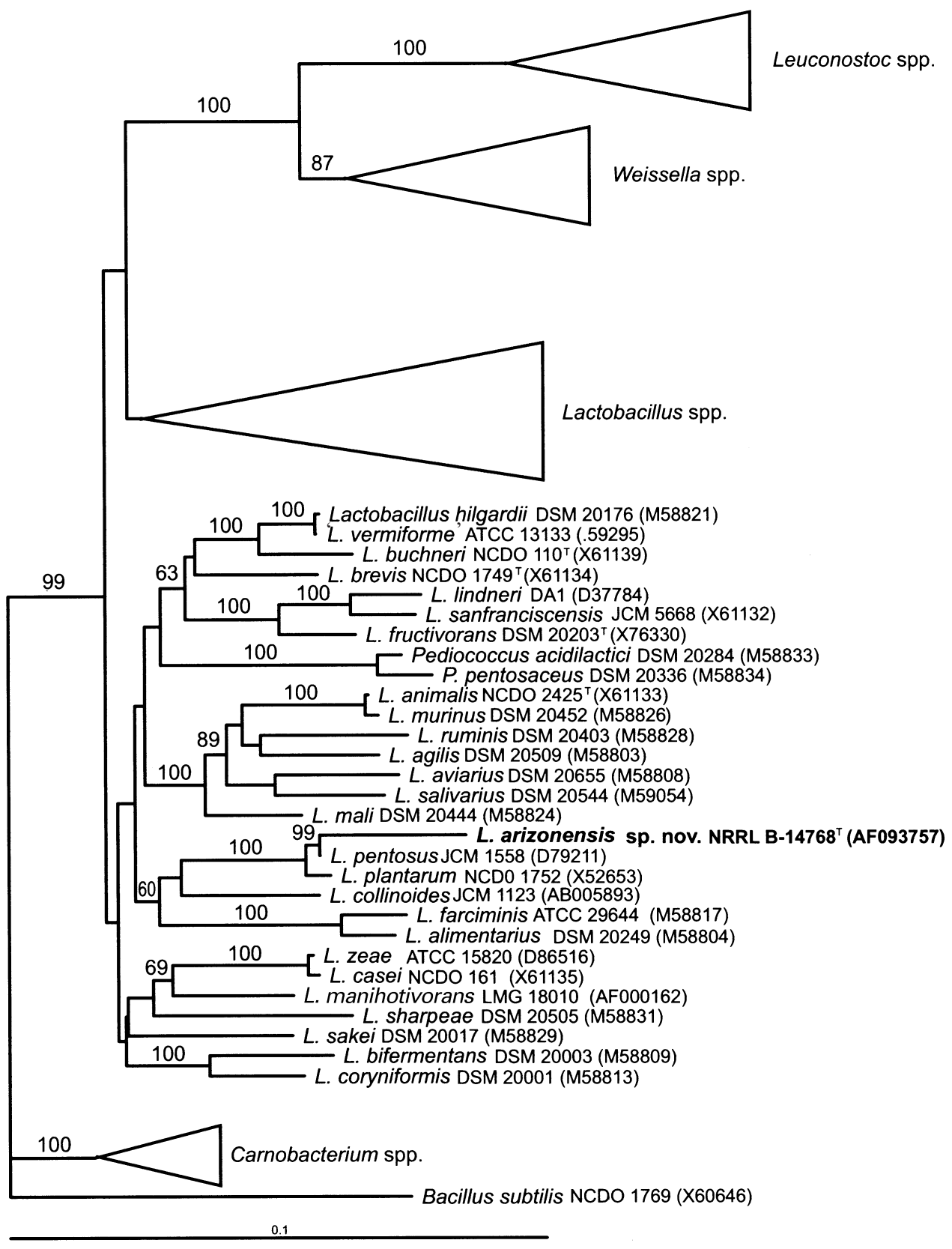

Fig. 1. Phylogenetic tree showing the position of Lactobacillus arizonensis NRRL $B-14768^{\top}$ among selected bacteria belonging to the Lactobacillaciae. The tree, which is rooted by using Bacillus subtilis as the outgroup, was generated by the neighbour-joining method. Bootstrap values based on 500 replications are given at the nodes. Trees generated by the neighbour-joining method and by maximum-parsimony analysis had similar topologies. GenBank accession numbers are given in parentheses. The bar represents $10 \%$ sequence divergence.

sorbitol and trehalose were fermented by all the isolates; L-arabinose and L-rhamnose were fermented only by NRRL B-14768 ${ }^{\mathrm{T}}$ and NRRL B-14769. Starch and D-xylose were not fermented. Other sugars fermented (not shown) were cellobiose, D-fructose, D-galactose, D-glucose (no gas produced), lactose, maltose, D-mannose, salicin and sucrose.

Analysis revealed that the isolates apparently produced only lactic acid $(0.046 \mathrm{~mol})$ from glucose
$(0.028 \mathrm{~mol})$ in $6 \mathrm{~d}$, and therefore the organisms are homofermentative. Theoretically, homofermentative conversion should yield $2 \mathrm{~mol}$ lactic acid for each mol glucose consumed. Therefore, the isolates converted approximately $80 \%$ of the glucose to lactic acid. Under optimum conditions L. delbrueckii (Schopmeyer, 1954) fermentations have given $95 \%$ yields. Determination with specific enzymes demonstrated that both $\mathrm{D}-(-)$ - and $\mathrm{L}-(+)$-lactic acids were produced. 
Table 2. DNA relatedness among the simmondsin degraders (SD) and Lactobacillus reference strains

Reassociation values are means of two determinations; the maximum difference found between determinations was $5 \%$. The values in parentheses indicate that, by definition, the reassociation value was $100 \%$.

\begin{tabular}{|c|c|c|c|c|c|}
\hline \multirow[t]{2}{*}{ Strain } & \multicolumn{5}{|c|}{ Reassociation (\%) to DNA from SD strains: } \\
\hline & $\begin{array}{c}\text { NRRL } \\
\text { B-14768 }\end{array}$ & $\begin{array}{c}\text { NRRL } \\
\text { B-14769 }\end{array}$ & $\begin{array}{c}\text { NRRL } \\
\text { B-14770 }\end{array}$ & $\begin{array}{c}\text { NRRL } \\
\text { B-14771 }\end{array}$ & $\begin{array}{c}\text { NRRL } \\
\text { B-14772 }\end{array}$ \\
\hline NRRL B-14768 & $(100)$ & & & & \\
\hline NRRL B-14769 & 71 & $(100)$ & & & \\
\hline NRRL B-14770 & 88 & 95 & $(100)$ & & \\
\hline NRRL B-14771 & 96 & 84 & 100 & $(100)$ & \\
\hline NRRL B-14772 & 87 & 70 & 86 & 89 & $(100)$ \\
\hline L. coryniformis $\mathrm{NRRL}$ B-4391 ${ }^{\mathrm{T}}$ & 39 & 37 & 30 & 31 & 29 \\
\hline L. plantarum NRRL B- $4496^{\mathrm{T}}$ & 42 & 40 & 38 & 39 & 42 \\
\hline L. paracasei subsp. paracasei NRRL B-4560 & 25 & 21 & 18 & 24 & 26 \\
\hline L. rhamnosus NRRL B-176 & 7 & 5 & 13 & 12 & 5 \\
\hline L. casei subsp. casei NRRL B-1922 ${ }^{\mathrm{T}}$ & 21 & 17 & 14 & 19 & 24 \\
\hline L. delbrueckii subsp. delbrueckii NRRL B-763 & 28 & 36 & 24 & 26 & 31 \\
\hline L. pentosus NRRL B- $473^{\mathrm{T}}$ & 39 & 31 & 29 & 33 & 36 \\
\hline
\end{tabular}

\section{S rDNA sequence}

Similarity values (not shown) of $95 \%$ established that NRRL B-14768 ${ }^{\mathrm{T}}$ was most closely related to members of the genus Lactobacillus. Values of $80-87 \%$ suggested a more distant relationship between NRRL B$14768^{\mathrm{T}}$ and the genus Carnobacterium. Data searches using the BLAST system (Altschul et al., 1990) corroborated the positioning of NRRL B- $14768^{\mathrm{T}}$ within the genus Lactobacillus, the closest relatives being $L$. plantarum and L. pentosus.

In a neighbour-joining tree (Fig. 1) based on sequences obtained in this study and from the GenBank database, NRRL B-14768 ${ }^{\mathrm{T}}$ is positioned in the $L$. casei/Pediococcus cluster (Collins et al., 1991). Thus, the data demonstrate that NRRL B- $14768^{\mathrm{T}}$ clearly belongs to the genus Lactobacillus and is closely related to L. plantarum and L. pentosus. This relationship was supported by the bootstrap analyses at a confidence level of $100 \%$.

\section{DNA base composition and reassociation}

The buoyant densities of the DNAs for the isolates ranged from 1.7069 to $1.7073 \mathrm{~g} \mathrm{ml}^{-1}$, which corresponds to $\mathrm{G}+\mathrm{C}$ contents of $47 \cdot 8-48 \cdot 3 \mathrm{~mol} \%$. These $\mathrm{G}+\mathrm{C}$ values are within the range reported for Lactobacillus (Kandler \& Weiss, 1986).

Table 2 shows that DNA relatedness ranging from 5 to $45 \%$ was obtained between the simmondsin-degrading strains and homofermentative Lactobacillus species having $\mathrm{G}+\mathrm{C}$ values of $45-50 \mathrm{~mol} \%$. DNA relatedness of $70-100 \%$ was measured among all simmondsindegrading strains. Studies have shown that microorganisms with DNA relatedness of $70 \%$ or higher belong to the same species (Johnson, 1973).

\section{DISCUSSION}

The simmondsin-degrading strains were isolated from fermenting jojoba meal on modified acetate agar (Rogosa et al., 1951), a selective medium for Lactobacillus species. These isolates were homofermentative, facultative, anaerobic or microaerophilic, Gram-positive, non-motile, non-spore-forming, rod-shaped cells that grew singly or in short chains and did not produce gas from glucose, were catalase-negative, and produced substantial amounts of lactic acid. These characteristics are typical of Lactobacillus species (Kandler \& Weiss, 1986; Rogosa \& Sharpe, 1960). Several characteristics eliminated the other 'regular, nonsporing, Gram-positive rods' as possible placements for the isolates. Carnobacterium species do not grow on acetate agar (Collins et al., 1987). Erysipelothrix Rosenbach 1909 (Jones, 1986), Brochothrix Sneath \& Jones 1976 (Sneath \& Jones, 1986) and Listeria Pirie 1940 (Seeliger \& Jones, 1986) often form filaments and have a $\mathrm{G}+\mathrm{C}$ range of $36-40 \mathrm{~mol} \%$; the latter two genera are also catalase-positive. Kurthia Trevisan 1885 (Keddie \& Shaw, 1986), Caryophanon Peshkoff 1939 (Trentini, 1986) and Renibacterium Sanders \& Fryer 1980 (Sanders \& Fryer, 1986) are strictly aerobic organisms. The granules revealed by Gram-staining are common in homofermentative Lactobacillus spp. (Kandler \& Weiss, 1986). The new isolates distinctly differ from the facultative anaerobic, lactic-acid-producing genera Staphylococcus Rosenbach 1884 (Kloos \& Schleifer, 1986), Streptococcus Rosenbach 1884 (Hardie, 1986), Leuconostoc van Tieghem 1878 (Garvie, 1986a) and Pediococcus Claussen 1903 (Garvie, 1986b), which exhibit definite coccoidal morphology. Also, classification of the new isolates as Bifidobacter was ruled out because this genus is strictly anaerobic, produces acetic acid as well as lactic acid, 
and has a $\mathrm{G}+\mathrm{C}$ range of $59-70 \mathrm{~mol} \%$ (Scardovi, 1986).

Phylogenetic analysis in the present study established that the isolates are members of the genus Lactobacillus. It is generally agreed that organisms exhibiting differences in $\mathrm{G}+\mathrm{C}$ contents no greater than $\pm 2 \%$ might be members of the same species (Johnson, 1973). According to Kandler \& Weiss (1986) $L$. plantarum, L. paracasei, L. casei, L. coryniformis, $L$. delbrueckii, L. pentosus and L. rhamnosus are homofermentative Lactobacillus species with $\mathrm{G}+\mathrm{C}$ contents within $2 \%$ of the $48 \mathrm{~mol} \%$ values of the new isolates. L. amylophilus is another species that meets this criterion (Nakamura \& Crowell, 1979). The DNA relatedness data in Table 2 indicate that the simmondsin-degrading isolates were unrelated to the reference strains of these established species. The new isolates are homofermenters and differ from the other homofermenters in a number of ways (Table 1). Whilst both simmondsin-degraders and L. rhamnosus grow at 15 and $45^{\circ} \mathrm{C}$, the latter species produces only L- $(+)$ lactic acid and does not ferment melibiose or raffinose. Additionally, in contrast to the new isolates, $L$. amylophilus, L. casei subsp. casei, L. delbrueckii and $L$. coryniformis do not produce both $\mathrm{D}-(-)-$ and $\mathrm{L}-(+)-$ lactic acid and, except for $L$. coryniformis, do not ferment melibiose and raffinose. Furthermore, $L$. amylophilus hydrolyses starch, a trait not shown by the simmondsin-degraders. Unlike the new isolates, $L$. plantarum, L. pentosus, L. coryniformis, L. amylophilus, L. casei and L. paracasei do not grow at $45^{\circ} \mathrm{C}$. The inability to ferment $\mathrm{D}$-xylose further distinguishes the simmondsin-degraders from L. pentosus. In contrast to the new isolates, $L$. paracasei does not ferment melibiose or raffinose. Furthermore, L. plantarum does not ferment L-rhamnose, an activity exhibited by some of the new isolates.

The evidence presented indicates that the simmondsindegrading Lactobacillus strains are members of a new species, for which the name Lactobacillus arizonensis is proposed. In spite of some minor differences in sugar fermentation patterns among the isolates, their consistently high DNA relatedness suggest that all isolates are members of single species.

\section{Description of Lactobacillus arizonensis sp. nov.}

Lactobacillus arizonensis (ar.i.zon'en.sis. L. gen. n. arizonensis named after the state in the United States where it was isolated).

Cells are rods, $1 \times 4 \cdot 0-5 \cdot 0 \mu \mathrm{m}$ in size, which occur singly and in short chains. Gram-positive and nonmotile. Endospores are not produced. Colonies on agar are white, convex, smooth, circular and opaque. In broth, growth causes turbidity which clears after a few days due to settling of cells. Acid is produced from cellobiose, D-fructose, D-galactose, D-glucose, lactose, maltose, D-mannitol, D-mannose, melibiose, raffinose, D-ribose, salicin, D-sorbitol, sucrose and trehalose.
Some strains may ferment L-( - )-arabinose and rhamnose, but D-xylose is not fermented. No gas is produced from D-glucose. $\mathrm{L}-(+)$ - and D- $(-)$-lactic acids are the only organic acids produced. Catalase is not produced. Facultatively anaerobic. Temperature relations are as follows: optimum, $35-40{ }^{\circ} \mathrm{C}$; minimum, $10-15^{\circ} \mathrm{C}$; maximum, $45-50{ }^{\circ} \mathrm{C} . \mathrm{G}+\mathrm{C}$ content is $48 \mathrm{~mol} \%$. Isolated from jojoba meal fermentations. The type strain is NRRL B-14768 ${ }^{\mathrm{T}}$ (= DSM $\left.13273^{\mathrm{T}}\right)$.

\section{ACKNOWLEDGEMENTS}

The authors are grateful to Michael Cotta for the lactic acid analyses and to Jill Pearsall for general technical help.

\section{REFERENCES}

Abbott, T. P., Nakamura, L. K., Nelson, T. L., Gasdorf, H. J., Bennett, G. A. \& Kleiman, R. (1990). Microorganisms for degrading simmondsin and related cyanogenic toxins in jojoba, Appl Microbiol Biotechnol 34, 270-273.

Altschul, S. F., Gish, W., Miller, W., Myers, E. W. \& Lipman, D. J. (1990). Basic local alignment search tool, J Mol Biol 215, 403-410.

Collins, M. D., Farrow, J. A. E., Phillips, B. A., Ferusu, S. \& Jones, D. (1987). Classification of Lactobacillus divergens, Lactobacillus piscicola, and some catalase-negative, asporogenous, rod-shaped bacteria from poultry in a new genus, Carnobacterium, Int J Syst Bacteriol 37, 310-316.

Collins, M. D., Rodriguez, U., Ash, C., Aguirre, M., Farrow, J. A. E., Martinez-Murcia, A., Philips, B. A., Williams, A. M. \& Walbanks, S. (1991). Phylogenetic analysis of the genus Lactobacillus and related lactic acid bacteria as determined by reverse transcriptase sequencing of $16 \mathrm{~S}$ rRNA, FEMS Microbial Lett 77, 5-12.

DeLey, J., Cattoir, H. \& Reynaerts, A. (1970). The quantitative measurement of DNA hybridization from renaturation rates, Eur J Biochem 12, 133-142.

Elliger, C. A., Waiss, A. C. \& Lundin, R. E. (1973). Simmondsin, an unusual 2-cyanomethylenecyclohexyl glucoside from Simmondsia californica, J Chem Soc Perkin Trans I 19, 2209-2212.

Elliger, C. A., Waiss, A. C. \& Lundin, R. E. (1974a). Structure and stereochemistry of simmondsin, J Org Chem 39, 2930-2931.

Elliger, C. A., Waiss, A. C. \& Lundin, R. E. (1974b). Cyanomethylenecyclohexyl glucosides from Simmondsia californica, Phytochemistry 13, 2319-2320.

Garvie, E. I. (1986a). Genus Leuconostoc van Tieghem 1878. In Bergey's Manual of Systematic Bacteriology, vol. 2, pp. 10711075. Edited by P. H. A. Sneath, N. S. Mair, M. E. Sharpe \& J. G. Holt. Baltimore: Williams \& Wilkins.

Garvie, E. I. (1986b). Genus Pediococcus Claussen 1903. In Bergey's Manual of Systematic Bacteriology, vol. 2, pp. 10751079. Edited by P. H. A. Sneath, N. S. Mair, M. E. Sharpe \& J. G. Holt. Baltimore: Williams \& Wilkins.

Hardie, J. M. (1986). Genus Streptococcus Rosenbach 1884. In Bergey's Manual of Systematic Bacteriology, vol. 2, pp. 10431071. Edited by P. H. A. Sneath, N. S. Mair, M. E. Sharpe \& J. G. Holt. Baltimore: Williams \& Wilkins.

Higgins, D. G., Bleasby, A. J. \& Fuchs, R. (1992). Clustal V: improved software for multiple sequence alignment, Comput Appl Biosci 8, 189-191. 
Johnson, J. L. (1973). Use of nucleic acid homologies in the taxonomy of anaerobic bacteria, Int $J$ Syst Bacteriol 23, 308-315.

Jones, D. (1986). Genus Erysipelothrix Rosenbach 1909. In Bergey's Manual of Systematic Bacteriology, vol. 2, pp. 1245-1249. Edited by P. H. A. Sneath, N. S. Mair, M. E. Sharpe \& J. G. Holt. Baltimore: Williams \& Wilkins.

Kandler, O. \& Weiss, N. (1986). Genus Lactobacillus Beijerinck 1901. In Bergey's Manual of Systematic Bacteriology, vol. 2, pp. 1209-1234. Edited by P. H. A. Sneath, N. S. Mair, M. E. Sharpe \& J. G. Holt. Baltimore: Williams \& Wilkins.

Keddie, R. M. \& Shaw, S. (1986). Genus Kurthia Trevisan 1885. In Bergey's Manual of Systematic Bacteriology, vol. 2, pp. 1255-1257. Edited by P. H. A. Sneath, N. S. Mair, M. E. Sharpe \& J. G. Holt. Baltimore: Williams \& Wilkins.

Kimura, M. (1980). A simple method for estimating evolutionary rate of base substitutions through comparative studies of nucleotide sequences, $J$ Mol Evol 16, 111-120.

Kloos, W. E. \& Schleifer, K. H. (1986). Genus Staphylococcus Rosenbach 1884. In Bergey's Manual of Systematic Bacteriology, vol. 2, pp. 1013-1035. Edited by P. H. A. Sneath, N. S. Mair, M. E. Sharpe \& J. G. Holt. Baltimore: Williams \& Wilkins.

Lane, D. L. (1991). 16S/23S rRNA sequencing. In Nucleic Acid Techniques in Bacterial Systematics, pp. 115-117. Edited by E. Stackebrandt \& M. Goodfellow. New York: Wiley.

Latorre-Guzman, B. A., Kado, C. I. \& Kunkee, R. E. (1977). Lactobacillus hordniae, a new species from the leafhopper [Hordnia ciscillata], Int J Syst Bacteriol 27, 362-370.

McClung, W. S. \& McCoy, E. (1934). Studies on anaerobic bacteria, J Bacteriol 28, 267-277.

Mandel, M. \& Marmur, J. (1968). Use of ultraviolet absorbancetemperature profile for determining the guanine plus cytosine content of DNA, Methods Enzymol 12B, 195-206.

Manos, C. G., Schrynemeeckers, P. J., Hogue, D. E. \& 7 other authors (1986). Toxicologic studies with lambs fed jojoba meal supplemented rations. J Agric Food Chem 34, 801-805.

Markov, G. C. \& Ivanov, I. G. (1974). Hydroxyapatite column chromatography procedure for isolation of purified DNA, Anal Biochem 59, 555-563.

Marmur, J. (1961). A procedure for the isolation of deoxyribonucleic acid from microorganisms, $J$ Mol Biol 3, 208-218.

Nakamura, L. K. \& Crowell, C. D. (1979). Lactobacillus amylophilus, a new starch-hydrolyzing species from swine waste-corn fermentation, Dev Ind Microbiol 20, 531-540.

Nakamura, L. K. \& Swezey, J. (1983). Taxonomy of Bacillus circulans Jordon 1890: base composition and reassociation of deoxyribonucleic acid, Int J Syst Bacteriol 33, 46-52.
Rogosa, M. \& Sharpe, M. E. (1960). An approach to the classification of the lactobacilli, J Appl Bacteriol 22, 329-340.

Rogosa, M., Mitchell, J. A. \& Wiseman, R. F. (1951). A selective medium for the isolation and enumeration of oral and fecal lactobacilli, J Bacteriol 62, 132-133.

Sanders, J. E. \& Fryer, J. L. (1986). Genus Renibacterium Sanders and Fryer 1980. In Bergey's Manual of Systematic Bacteriology, vol. 2, pp. 1253-1254. Edited by P. H. A. Sneath, N. S. Mair, M. E. Sharpe \& J. G. Holt. Baltimore: Williams \& Wilkins.

Scardovi, V. (1986). Genus Bifidobacterium Orla-Jensen 1924. In Bergey's Manual of Systematic Bacteriology, vol. 2, pp. 1418-1434. Edited by P. H. A. Sneath, N. S. Mair, M. E. Sharpe \& J. G. Holt. Baltimore: Williams \& Wilkins.

Schildkraut, C. L., Marmur, J. \& Doty, P. (1962). Determination of the base composition of deoxyribonucleic acid from its buoyant density in $\mathrm{CsCl}, J$ Mol Biol 4, 430-443.

Schopmeyer, H. H. (1954). Lactic Acid. In Industrial Fermentation, vol. 1, pp. 391-419. Edited by L. A. Underkofler \& R. J. Hickley. New York: Chemical Publishing Co.

Seeliger, J. P. R. \& Jones, D. (1986). Genus Listeria Pirie 1940. In Bergey's Manual of Systematic Bacteriology, vol. 2, pp. 1235-1245. Edited by P. H. A. Sneath, N. S. Mair, M. E. Sharpe \& J. G. Holt. Baltimore: Williams \& Wilkins.

Shimizu, G. P., Cotta, M. A. \& Bothast, R. J. (1989). The kinetics of glucose fermentation by Selenomonas ruminantium HD4 grown in continuous culture, Biotechnol Lett 11, 67-72.

Sneath, P. H. A. \& Jones, D. (1986). Genus Brochothrix Sneath and Jones 1976. In Bergey's Manual of Systematic Bacteriology, vol. 2, pp. 1249-1253. Edited by P. H. A. Sneath, N. S. Mair, M. E. Sharpe \& J. G. Holt. Baltimore: Williams \& Wilkins.

Trentini, W. C. (1986). Genus Caryophanon Peshkoff 1939. In Bergey's Manual of Systematic Bacteriology, vol. 2, pp. 1259-1260. Edited by P. H. A. Sneath, N. S. Mair, M. E. Sharpe \& J. G. Holt. Baltimore: Williams \& Wilkins.

Verbiscar, A. J. \& Banigan, T. F. (1978). Composition of jojoba seeds and foliage, J Agric Food Chem 26, 1456-1459.

Verbiscar, A. J., Banigan, T. F., Weber, C. W., Reid, B. L., Swingle, R. S., Trei, J. E. \& Nelson, E. A. (1981). Detoxification of jojoba meal by Lactobacilli, J Agric Food Chem 29, 296-302.

Weber, C. W., Berry, J. W. \& Cook, E. M. (1983). Influence of jojoba meal upon growth and reproduction in mice. In Jojoba and Its Use Through 1982. Proceedings of the Fifth International Conference on Jojoba and Its Use. Edited by A. Elias-Cesnik. Tucson, AZ: Office of Arid Lands Studies, University of Arizona.

Zanoni, P., Farrow, J. A., Phillips, B. \& Collins, M. (1987). Lactobacillus pentosus sp. nov., nom. rev, Int J Syst Bacteriol 37, 339-341. 